\title{
Haemodynamic effects of atenolol in patients with coronary artery disease
}

\author{
CHRISTINE ROBINSON ${ }^{1}$, GORDON JACKSON, CLIVE FISK, AND \\ DAVID JEWITT
}

From the Cardiac Department, King's College Hospital, Denmark Hill, London

The haemodynamic effects of atenolol, a new cardioselective beta-blocking agent, have been studied at rest in 8 patients with coronary artery disease. The drug was administered intravenously in cumulative doses of $0.03,0.06$, and $0.12 \mathrm{mg} / \mathrm{kg}$ body weight. A significant decrease in heart rate was associated with a fall in cardiac output. However, this cardiac output fall was not entirely rate dependent, since stroke volume fell significantly both during spontaneous sinus rhythm and when heart rate was maintained constant by atrial pacing. A dose related and significant reduction occurred in left ventricular $d P / d t$ max without significant change in left ventricular filling pressure or mean aortic pressure. Total peripheral resistance at rest rose after atenolol. The haemodynamic findings more closely resemble those which follow intravenous propranolol than those after intravenous practolol in a similar group of patients. These actions of atenolol suggest that it may be a useful agent in the treatment of patients with angina pectoris.

Beta-adrenergic blocking agents have established value in the management of patients with angina pectoris, hypertension, and cardiac arrhythmias (Epstein and Braunwald, 1966). Of the agents clinically available, propranolol has been most extensively investigated (Prichard and Gillman, 1964; Gibson and Sowton, 1969; Lesch and Gorlin 1973). The introduction of practolol, a relatively cardioselective beta-adrenergic blocking agent, provided a drug which could be used with caution in patients with hypertension or angina who also had obstructive airways disease (MacDonald and McNeill, 1968; Powles et al., 1969). In addition practolol was shown to be an effective drug in the management of a variety of supraventricular and ventricular arrhythmias occurring in patients with coronary artery disease (Gibson et al., 1968; Jewitt et al., 1969). However, subsequent experience has shown that practolol, when given orally, results in important long-term side effects. These include the oculomucocutaneous syndrome (Brown et al., 1974; Felix et al., 1974; Wright, 1975) and a lupus erythematosus-like syndrome (Raftery and Denman, 1973). In consequence practolol has been withdrawn from general clinical use.

Atenolol (Tenormin, I.C.I. 66082) (Fig. 1) is a new beta-adrenergic receptor blocking drug which

${ }^{1}$ In receipt of a British Heart Foundation Junior Research Fellowship. Received for publication 23 March 1977
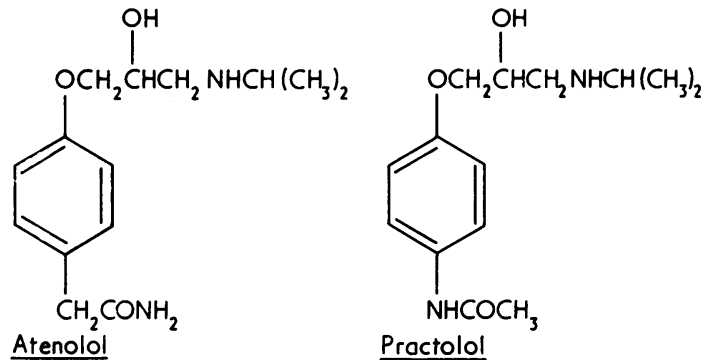

Fig. 1 Structural formulae of atenolol and practolol.

has been shown in animal studies to possess equivalent cardioselectivity to practolol. Pharmacologically it also resembles practolol in lacking membrane stabilising properties, but in contrast it does not possess intrinsic sympathomimetic activity (Barrett et al., 1973). In man the beta-blocking activity (Conway et al., 1976) and relative cardioselectivity (Vilsvik and Schaanning, 1976) of atenolol have been confirmed. A cardioselective beta-blocking drug would have, like practolol in the past, a potential role in the management of angina pectoris, hypertension, and cardiac arrhythmias, particularly in patients with airways obstruction.

The present study was designed to investigate the effects of increasing doses of atenolol on heart rate, cardiac output, left ventricular contractile state, and left ventricular filling pressure in patients 
Table 1 Clinical details of patients

\begin{tabular}{|c|c|c|c|c|}
\hline Case No. & Age & $\operatorname{Sex}$ & Electrocardiogram & Coronary arteriography and left ventriculography \\
\hline 1 & 62 & $M$ & $\begin{array}{l}\text { Anteroseptal myocardial infarct with } \\
\text { anterolateral ischaemia }\end{array}$ & $\begin{array}{l}\text { LV aneurysm; } 50 \% \text { stenosis in right coronary artery } \\
\text { (RCA); } 80 \% \text { stenosis in right posterior descending; } \\
\text { total occlusion of left anterior descending (LAD) } \\
\text { proximally, with retrograde filling from RCA by } \\
\text { collaterals; total occlusion of left circumflex (LCx) } \\
2 \mathrm{~cm} \text { from origin }\end{array}$ \\
\hline 2 & 63 & $\mathbf{M}$ & ST depression in leads I, II, V4-6 & $\begin{array}{l}\text { Apical LV dyskinesia; RCA totally occluded } 2 \mathrm{~cm} \text { from } \\
\text { origin, posterior descending filling retrogradely from } \\
\text { left coronary; } 90 \%+\text { stenosis of LAD with good } \\
\text { distal run off; small LCx }\end{array}$ \\
\hline 3 & 52 & $\mathbf{F}$ & $\begin{array}{l}\text { ST elevation in leads II, III, VF, during } \\
\text { chest pain; normal at rest }\end{array}$ & $\begin{array}{l}\text { Normal LV; } 30 \% \text { funnel narrowing of RCA; two } 50 \% \\
\text { stenoses of LAD } 6 \mathrm{~cm} \text { from origin }\end{array}$ \\
\hline 4 & 38 & $\mathbf{M}$ & Inferolateral myocardial infarct & $\begin{array}{l}\text { Inferior LV dyskinesia; total occlusion of RCA; } 90 \% \\
\text { stenosis of LAD } 5 \mathrm{~cm} \text { from origin, good run off; } \\
90 \% \text { stenosis left diagonal; LCx totally occluded; } \\
\text { retrograde filling of right posterior descending from } \\
\text { LAD }\end{array}$ \\
\hline 5 & 47 & $\mathbf{M}$ & $\begin{array}{l}\text { Widespread } S T, T \text { wave changes consistent } \\
\text { with ischaemia }\end{array}$ & $\begin{array}{l}\text { Inferior LV dyskinesia; total occlusion of RCA } \\
\text { proximally; total occlusion of LCx } 2 \mathrm{~cm} \text { from origin, } \\
\text { good run off }\end{array}$ \\
\hline 6 & 45 & $\mathbf{M}$ & Normal & $\begin{array}{l}\text { Normal LV; } 30 \% \text { funnel narrowing of RCA; } 90 \% \\
\text { stenosis of LAD at first septal branch }\end{array}$ \\
\hline 7 & 43 & $\mathbf{M}$ & $\mathrm{T}$ wave inversion in leads V4-V6 & Normal LV and coronary arteries \\
\hline 8 & 46 & $\mathbf{M}$ & Anterolateral myocardial infarct & Blocked LCx; stenosis of RCA and LAD \\
\hline
\end{tabular}

with established coronary artery disease. A specific objective was to relate these findings to those previously reported after the administration of propranolol or practolol to similar patients. A specific question was whether the relative cardiospecificity of atenolol, in the absence of intrinsic sympathomimetic activity, would lead to haemodynamic effects more like those of practolol than propranolol.

\section{Subjects and methods}

Studies were performed on 8 patients with coronary artery disease or angina pectoris undergoing routine cardiac catheterisation and coronary arteriography before surgery. Clinical details of these patients are shown in Table 1. Informed consent was obtained from each patient after the nature of the procedure had been fully explained. All medication apart from sublingual nitroglycerin was withdrawn at least two days before the procedure. A premedication of diazepam $10 \mathrm{mg}$ intramuscularly was given before catheterisation. Right heart catheterisation was performed via a medial anticubital vein while left heart catheterisation, ventriculography, and coronary arteriography were performed using a Seldinger technique via the femoral arterial route. Haemodynamic measurements were not started until at least 45 minutes after the completion of angiography. In 6 of the 8 patients a No. 5 bipolar pacing catheter was placed in the right atrium so that the heart could be paced at a constant rate of 90 beats $/ \mathrm{min}$. Observations were made in a control state during spontaneous sinus rhythm and also during right atrial pacing at a constant rate for more than 5 minutes. These observations were repeated after the administration of atenolol. Atenolol was given by separate slow intravenous injections, each over a period of 5 minutes into a vein on the back of the hand. The cumulative doses achieved were $0.03,0.06$, and $0.12 \mathrm{mg} / \mathrm{kg}$ body weight. Observations were made 5 minutes after the end of each injection during spontaneous sinus rhythm in all patients, and during right atrial pacing at a constant rate of 90 beats $/ \mathrm{min}$ in 6 of the 8 patients.

\section{HAEMODYNAMIC MEASUREMENTS}

Aortic, pulmonary artery, and left ventricular enddiastolic pressures were measured via a fluid filled manometer with Elema Schonander 746 pressure transducers and recorded on an Elema Schonander Mingograph 82. Systolic and diastolic pressures were calculated by averaging individual systolic and diastolic points for at least 10 heart beats. The mean pressures in the aorta and pulmonary artery were derived electronically. A left ventricular pressure signal was taken with a Millar strain gauge catheter using a Millar TCB 100 control unit. This signal was then differentiated electronically by an Elema Schonander Mingograph 82 differentiator module to record the rate of change of left ventricular pressure (LV dP/dt). Cardiac outputs were determined by the indocyanine green dye dilution method with a Gilford densitometer. Oxygen saturations were measured using a radiometer, and haemoglobin estimations were made on a Coulter $S$ machine. 


\section{Derived values}

Systemic vascular resistance $=$

$$
\frac{\overline{(\mathrm{BP})}}{\mathrm{CO}} \times 80 \text { dynes.s. } \mathrm{cm}^{-5}
$$

(assuming right atrial pressure to be zero)

Pulmonary vascular resistance $=$

$$
\frac{\overline{(\mathrm{PA}-L V E D P})}{\mathrm{CO}} \times 80 \text { dynes.s. } \mathrm{cm}^{-5}
$$

(assuming LVEDP to be the same as the mean left atrial pressure).

\section{STATISTICAL ANALYSIS}

Paired data were analysed using Student's $t$ test on a two-tail basis.

\section{Results}

The observations were made during spontaneous sinus rhythm in all 8 patients and in 6 of these patients while the heart rate was maintained constant by atrial pacing at a rate of 90 beats $/ \mathrm{min}$.
Tables 2 and 3 show the effects of the three doses of atenolol $(0.03,0.06$, and $0.12 \mathrm{mg} / \mathrm{kg}$ body weight) on haemodynamic variables and indicate whether or not there is a significant change from the control value in each case.

\section{HEART RATE}

Heart rate was significantly reduced by atenolol at each dose level. The control level of $69 \pm 2$ beats/ min was reduced by a mean value of $8 \pm 2$ beats/ min at a dose of $0.03 \mathrm{mg} / \mathrm{kg}(P<0.01)$, by $9 \pm 2$ beats $/ \mathrm{min}$ at a dose of $0.06 \mathrm{mg} / \mathrm{kg}(\mathrm{P}<0.01)$, and by $10 \pm 2$ beats $/ \mathrm{min}$ at a dose of $0.12 \mathrm{mg} / \mathrm{kg}$ body weight $(P<0.01)$. The last change represents a fall of 14 per cent from control. There was no significant difference between the effects of each dose.

\section{CARDIAC OUTPUT}

Cardiac output was significantly reduced by atenolol at each dose level (Fig. 2). During spontaneous sinus rhythm the mean control value of $4.0 \pm 0.31$ / $\min$ fell by $0.64 \pm 0.1 \mathrm{l} / \mathrm{min}$ at a dose of 0.03 $\mathrm{mg} / \mathrm{kg}(\mathrm{P}<0.01)$, by $0.94 \pm 0.11 / \mathrm{min}$ at a dose of $0.06 \mathrm{mg} / \mathrm{kg}(P<0.01)$, and by $0.93 \pm 0.21 / \mathrm{min}$ at a

\begin{tabular}{|c|c|c|c|c|}
\hline & Control & $\begin{array}{l}\text { After atenolol } \\
(0.03 \mathrm{mg} / \mathrm{kg})\end{array}$ & $\begin{array}{l}\text { After atenolol } \\
(0.06 \mathrm{mg} / \mathrm{kg})\end{array}$ & $\begin{array}{c}\text { After atenolol } \\
(0.12 \mathrm{mg} / \mathrm{kg})\end{array}$ \\
\hline $\begin{array}{l}\text { Heart rate (beats/min) } \\
\text { Cardiac output }(1 / \mathrm{min}) \\
\text { Stroke volume (ml) } \\
\text { Pressures (mmHg) }\end{array}$ & $\begin{array}{l}69 \pm 2 \\
4 \cdot 0 \pm 0 \cdot 3 \\
65 \pm 7\end{array}$ & $\begin{aligned} 62 & \pm 2 \star \star \star \\
3 \cdot 4 & \pm 0 \cdot 2 \star \star \star \\
62 & \pm 6\end{aligned}$ & $\begin{aligned} 61 & \pm 2 \star \star \star \\
3 \cdot 1 & \pm 0 \cdot 2^{\star \star \star} \\
57 & \pm 6^{\star}\end{aligned}$ & $\begin{aligned} 60 & \pm 3 \star \star \star \\
2 \cdot 9 & \pm 0 \cdot 3 \star \star \star \\
57 & \pm 9\end{aligned}$ \\
\hline $\begin{array}{l}\text { Aorta (mean) } \\
\text { Pulmonary artery (mean) } \\
\text { LV end-diastolic } \\
\text { LV dP/dt max (mmHg/s) } \\
\text { Resistances (dynes.s.cm }{ }^{-5} \text { ) }\end{array}$ & $\begin{aligned} 89 & \pm 6 \\
15 & \pm 1 \\
9 & \pm 1 \\
1555 & \pm 159\end{aligned}$ & $\begin{aligned} 91 & \pm 6 \\
16 & \pm 1 \\
10 & \pm 1 \\
1429 & \pm 152^{\star \star}\end{aligned}$ & $\begin{aligned} 89 & \pm 4 \\
16 & \pm 1 \\
10 & \pm 1 \\
1236 & \pm 110^{\star \star \star}\end{aligned}$ & $\begin{aligned} 85 & \pm 4 \\
15 & \pm 1 \\
10 & \pm 1 \\
1214 & \pm 92 \star \star \star\end{aligned}$ \\
\hline $\begin{array}{l}\text { Systemic vascular } \\
\text { Pulmonary vascular } \\
\text { AV } \mathrm{O}_{2} \text { difference }(\mathrm{ml} / 100 \mathrm{ml}) \\
\mathrm{O}_{2} \text { consumption }(\mathrm{ml} / \mathrm{min})\end{array}$ & $\begin{array}{c}1815 \pm 110 \\
107 \pm 24 \\
5 \cdot 7 \pm 0 \cdot 8 \\
237 \pm 33\end{array}$ & $\begin{aligned} 2253 & \pm 181 \star \star \star \\
154 & \pm 25 \\
6 \cdot 1 & \pm 1 \cdot 1 \\
214 & \pm 37 \star\end{aligned}$ & $\begin{aligned} 2427 & \pm 170^{\star \star \star} \\
186 & \pm 52 \\
6 \cdot 0 & \pm 0 \cdot 8 \\
194 & \pm 28\end{aligned}$ & $\begin{aligned} 2501 & \pm 284^{\star \star} \\
189 & \pm 65 \\
6 \cdot 0 & \pm 0 \cdot 8 \\
197 & \pm 34\end{aligned}$ \\
\hline
\end{tabular}

Table 2 Haemodynamic effects of graded doses of atenolol during spontaneous sinus rhythm

$\star \star \star, P<0.01 ; \star \star, P<0.02 ; \star, P<0.05$.

\begin{tabular}{|c|c|c|c|c|}
\hline & Control & $\begin{array}{l}\text { After atenolol } \\
(0.03 \mathrm{mg} / \mathrm{kg})\end{array}$ & $\begin{array}{l}\text { After atenolol } \\
(0.06 \mathrm{mg} / \mathrm{kg})\end{array}$ & $\begin{array}{l}\text { After atenolol } \\
(0.12 \mathrm{mg} / \mathrm{kg})\end{array}$ \\
\hline $\begin{array}{l}\text { Cardiac output (1/min) } \\
\text { Stroke volume }(\mathrm{ml}) \\
\text { Pressures (mmHg) }\end{array}$ & $\begin{aligned} 4 \cdot 3 & \pm 0 \cdot 3 \\
49 & \pm 4\end{aligned}$ & $\begin{array}{c}3 \cdot 9 \pm 0 \cdot 3^{\star \star} \\
44 \pm 4^{\star \star}\end{array}$ & $\begin{array}{l}3.5 \pm 0.3 \star \star \star \\
39 \pm 4 \star \star \star\end{array}$ & $\begin{array}{l}3 \cdot 2 \pm 0 \cdot 2 \star \star \star \\
37 \pm 3 \star \star \star\end{array}$ \\
\hline $\begin{array}{l}\text { Aorta (mean) } \\
\text { Pulmonary artery (mean) } \\
\text { LV end-diastolic } \\
\text { LV dP/dt max (mmHg/s) } \\
\text { Resistances (dynes.s.cm-5) }\end{array}$ & $\begin{aligned} 94 & \pm 10 \\
14 & \pm 2 \\
9 & \pm 2 \\
1652 & \pm 189\end{aligned}$ & $\begin{aligned} 98 & \pm 8 \\
14 & \pm 1 \\
8 & \pm 1 \\
1473 & \pm 169 \star\end{aligned}$ & $\begin{aligned} 93 & \pm 5 \\
13 & \pm 1 \\
8 & \pm 1 \\
1318 & \pm 122 \star \star \star\end{aligned}$ & $\begin{aligned} 85 & \pm 3 \\
14 & \pm 1 \\
8 & \pm 1 \\
1202 & \pm 102 \star \star\end{aligned}$ \\
\hline $\begin{array}{l}\text { Systemic vascular } \\
\text { Pulmonary vascular } \\
\text { AV } \mathrm{O}_{2} \text { difference }(\mathrm{ml} / 100 \mathrm{ml}) \\
\mathrm{O}_{2} \text { consumption }(\mathrm{ml} / \mathrm{min})\end{array}$ & $\begin{aligned} 1758 & \pm 150 \\
96 & \pm 18 \\
5 \cdot 7 & \pm 0 \cdot 3 \\
245 & \pm 18\end{aligned}$ & $\begin{aligned} 2072 & \pm 196 \star \\
114 & \pm 10 \\
5 \cdot 8 & \pm 0 \cdot 4 \\
238 & \pm 40\end{aligned}$ & $\begin{aligned} 2211 & \pm 176 \star \\
128 & \pm 32 \\
5 \cdot 7 & \pm 0 \cdot 6 \\
200 & \pm 43\end{aligned}$ & $\begin{aligned} 2181 & \pm 191 \\
118 & \pm 38 \\
6 \cdot 0 & \pm 0 \cdot 9 \\
197 & \pm 59\end{aligned}$ \\
\hline
\end{tabular}

Table 3 Haemodynamic effects of graded doses of atenolol during atrial pacing at a constant rate

$\star \star \star, P<0.01 ; \star \star, P<0.02 ; \star, P<0.05$. 


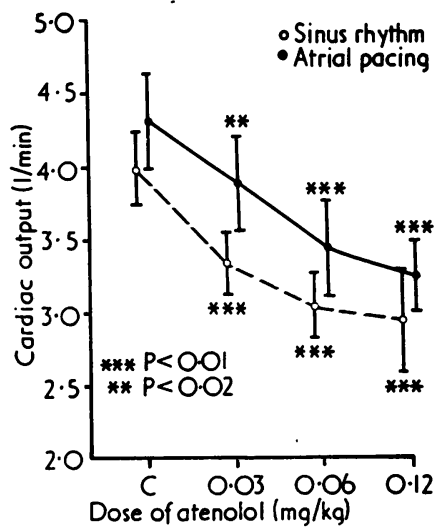

Fig. 2 Mean changes in cardiac output in patients receiving graded doses of atenolol during sinus rhythm and during atrial pacing at a constant rate.

dose of $0.12 \mathrm{mg} / \mathrm{kg}(P<0.01)$. The last represented a fall of 23 per cent. The effect of the $0.12 \mathrm{mg} / \mathrm{kg}$ dose was significantly greater than that of the $0.03 \mathrm{mg} / \mathrm{kg}$ dose $(P<0.05)$ but otherwise there was no significant difference between the three dose levels.

During atrial pacing, cardiac output was also significantly reduced from a mean control value of $4.3 \pm 0.3 \mathrm{l} / \mathrm{min}$, by $0.47 \pm 0.1 \mathrm{l} / \mathrm{min}$ at a dose of $0.03 \mathrm{mg} / \mathrm{kg}(\mathrm{P}<0.02)$, by $0.88 \pm 0.1 \mathrm{l} / \mathrm{min}$ at a dose of $0.6 \mathrm{mg} / \mathrm{kg}(P<0.01)$, and by $1.1 \pm 0.21 / \mathrm{min}$ at a dose of $0.12 \mathrm{mg} / \mathrm{kg}(P<0.01)$. The last change represented a fall of 25 per cent from the control value. The effects of the 0.06 and the $0.12 \mathrm{mg} / \mathrm{kg}$ doses were significantly greater than that of the $0.03 \mathrm{mg} / \mathrm{kg}$ dose $(P<0.02)$, but there was no significant difference between the effects of the two higher doses.

\section{STROKE VOLUME}

Although there was no significant change in stroke volume after atenolol 0.03 and $0.12 \mathrm{mg} / \mathrm{kg}$ during sinus rhythm there was a mean fall of $7 \cdot 6 \pm 2.6 \mathrm{ml}$ after a dose of $0.06 \mathrm{mg} / \mathrm{kg}(P<0.05)$ from the control value of $64 \cdot 9 \pm 7 \cdot 1 \mathrm{ml}$ (Fig. 3). During atrial pacing, stroke volume was significantly reduced at all 3 dose levels. There was a fall of $5.7 \pm 1.4 \mathrm{ml}$ at $0.03 \mathrm{mg} / \mathrm{kg}(P<0.02)$, of $10.2 \pm 1.5 \mathrm{ml}$ at $0.06 \mathrm{mg} / \mathrm{kg}$ $(P<0.01)$, and of $12.7 \pm 2.6$ at a dose of $0.12 \mathrm{mg} / \mathrm{kg}$ $(P<0.01)$. The last change represents a fall of 26 per cent from the control value. The effects of the 0.06 and the $0.12 \mathrm{mg} / \mathrm{kg}$ doses were significantly greater than those of the $0.03 \mathrm{mg} / \mathrm{kg}$ dose $(P<0.05)$, but the effects of the two higher doses were not significantly different.

\section{CARDIOVASCULAR PRESSURES}

There was no significant change in mean aortic or pulmonary artery pressures or left ventricular enddiastolic pressure after atenolol.

\section{LEFT VENTRICULAR $\mathrm{dP} / \mathrm{dt} \max$}

Left ventricular $\mathrm{dP} / \mathrm{dt}$ max was significantly reduced by atenolol at all three dose levels studied (Fig. 4). During spontaneous sinus rhythm, the mean control value of $1555 \pm 159 \mathrm{mmHg} / \mathrm{s}$ fell by $127 \pm$ 40 at a dose of $0.03 \mathrm{mg} / \mathrm{kg}(P<0.02)$, by $320 \pm 81$ at $0.06 \mathrm{mg} / \mathrm{kg}(P<0.01)$, and by $342 \pm 83$ at 0.12

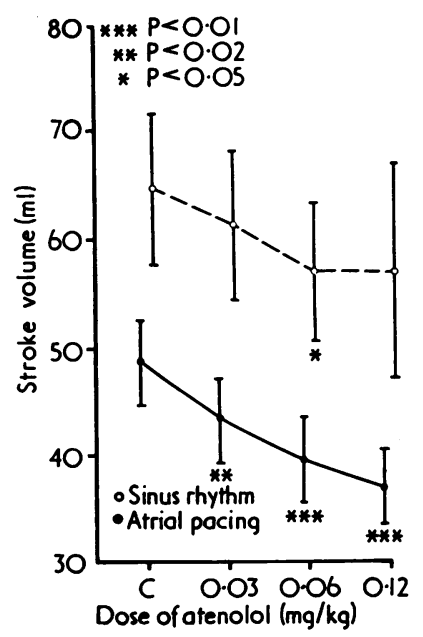

Fig. 3 Mean changes in stroke volume in patients receiving graded doses of atenolol during sinus rhythm and during atrial pacing at a constant rate.

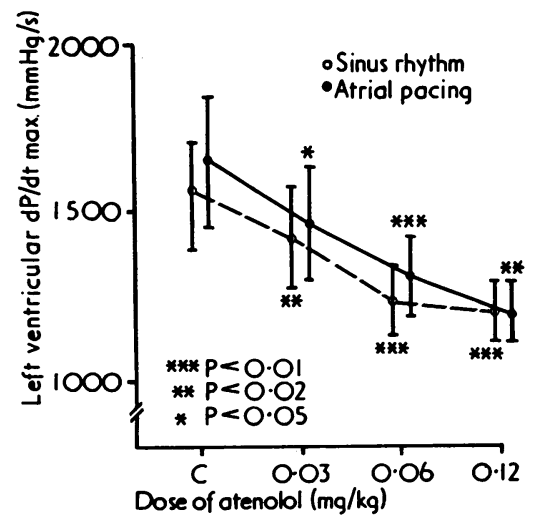

Fig. 4 Mean changes in left ventricular $d P / d t$ max in patients receiving graded doses of atenolol during sinus rhythm and during atrial pacing at a constant rate. 
$\mathrm{mg} / \mathrm{kg}(P<0.01)$. The last change represents a fall of 22 per cent from the mean control value. The effects of the 0.06 and the $0.12 \mathrm{mg} / \mathrm{kg}$ doses were significantly greater than those of the $0.03 \mathrm{mg} / \mathrm{kg}$ dose $(P<0.05)$, but there was no significant difference between the effects of the two higher doses. During atrial pacing, the mean control value of $1652 \pm 189 \mathrm{mmHg} / \mathrm{s}$ fell by $179 \pm 53$ at a dose of $0.03 \mathrm{mg} / \mathrm{kg}(\mathrm{P}<0.05)$, by $334 \pm 73$ at $0.06 \mathrm{mg} / \mathrm{kg}$ $(P<0.01)$, and by $450 \pm 123$ at $0.12 \mathrm{mg} / \mathrm{kg}(P<0.02)$. There was no significant difference between the effects of any of the three dose levels.

\section{OXYGEN CONSUMPTION}

Oxygen consumption tended to fall after atenolol. The mean control value of $237 \pm 33 \mathrm{ml} / \mathrm{min}$ fell by $23 \pm 6$ after $0.03 \mathrm{mg} / \mathrm{kg}(\mathrm{P}<0.05)$ and there was a statistically insignificant fall after 0.06 and $0.12 \mathrm{mg}$ / kg.

\section{SYSTEMIC VASCULAR RESISTANCE}

Systemic vascular resistance increased consistently after atenolol (Fig. 5). During spontaneous sinus rhythm, the mean control value of $1815 \pm 110$ dynes.s.cm ${ }^{-5}$ rose by $438 \pm 78$ after a dose of $0.03 \mathrm{mg} / \mathrm{kg}(\mathrm{P}<0.01)$, by $612 \pm 102$ after 0.06 $\mathrm{mg} / \mathrm{kg}(\mathrm{P}<0.01)$, and by $729 \pm 185$ after $0.12 \mathrm{mg} / \mathrm{kg}$ $(P<0.02)$. There was no significant difference between the three dose levels used. During atrial pacing the mean control value of $1758 \pm 150$ dynes.s.cm ${ }^{-5}$ rose by $314 \pm 110$ after $0.03 \mathrm{mg} / \mathrm{kg}$ $(P<0.05)$, by $453 \pm 147$ after $0.06 \mathrm{mg} / \mathrm{kg}(P<0.05)$, and by $423 \pm 232$ after $0 \cdot 12 \mathrm{mg} / \mathrm{kg}$.

\section{PULMONARY VASCULAR RESISTANCE}

Pulmonary vascular resistance showed a modest rise after administration of atenolol but this was not sig-

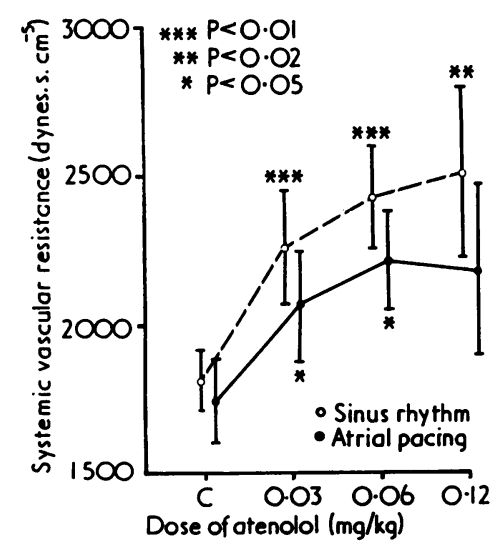

Fig. 5 Mean changes in systemic vascular resistance in patients receiving graded doses of atenolol during sinus rhythm and during atrial pacing at a constant rate. nificant either during spontaneous sinus rhythm or during atrial pacing.

\section{Discussion}

The present study of atenolol was conducted in patients with coronary artery disease. The drug produced a decrease in resting heart rate which was significant with the lowest dose, with only marginal further reductions as the dose was increased. The reduction in cardiac output was not associated with any significant change in mean aortic pressure. These findings confirm those previously reported by Asström and Vallin (1974). In contrast, the fall in cardiac output in the present study was associated with a significant fall in stroke volume in patients whose heart rate was maintained constant at 90 beats per minute by atrial pacing. This fall in stroke volume during atrial pacing was significant at all three dose levels of atenolol. During spontaneous sinus rhythm there was also a fall in stroke volume which was significant at a dose of $0.06 \mathrm{mg} / \mathrm{kg}$. Therefore the fall in cardiac output observed after atenolol was not purely rate dependent. These observations are comparable with those reported when propranolol was adminstered intravenously to patients with coronary artery disease (Hamer and Sowton, 1965). In contrast, the modest fall in cardiac output which follows intravenous practolol in equivalent beta-blocking doses is rate dependent and stroke volume in fact rises (Sowton et al., 1968; Jewitt et al., 1970).

Mean aortic pressure and left ventricular enddiastolic pressure did not change significantly after atenolol during spontaneous sinus rhythm or during atrial pacing at 90 beats per minute. There was a dose related reduction in the maximum rate of rise of left ventricular pressure after atenolol. However, since left ventricular filling pressure and aortic diastolic pressure were not rigidly controlled and variations in these variables will influence left ventricular $d P / d t$, caution is necessary in interpreting this change. Calculated $\mathrm{V}$ max values (Mason et al., 1970) obtained from the present data, show a similar and consistent reduction after atenolol. However, there is no universal agreement that this or any other single isovolumic index of myocardial contractility is truly independent of preload, afterload, and heart rate change. These derivations are therefore not presented. However, the magnitude of the reductions in left ventricular $\mathrm{dP} / \mathrm{dt}$ max observed after atenolol, in the absence of significant change in left ventricular filling pressure and mean aortic pressure, probably represents a true reduction in left ventricular contractile state. This would result from competitive blockade of 
cardiac sympathetic nervous discharge or blockade of the action of circulating catecholamines on the heart.

Systemic vascular resistance increased significantly after atenolol in the patients studied here at rest, confirming the previous report by Åström and Vallin (1974). Similar observations have been reported after intravenous propranolol (Åström, 1968). In contrast, when practolol was administered intravenously to patients with coronary artery disease, no significant change in systemic vascular resistance occurred (Sowton et al., 1968; Jewitt et al., 1970). Therefore, at rest the effect of atenolol on peripheral vascular resistance is similar to that of propranolol and differs from that of practolol. On exercise, however, Asström and Vallin (1974) noted that there was no significant change in systemic vascular resistance after atenolol because the lower aortic pressure was associated with the decrease in cardiac output. These observations more closely resembled those after intravenous practolol (Gibson and Sowton, 1968) than those after intravenous propranolol. That the similarity between atenolol and practolol was apparent only on exercise may indicate that, though atenolol is relatively cardiospecific, the absence of peripheral vascular betablockade is only apparent when high circulating levels of adrenaline produce beta-adrenergic receptor-mediated peripheral vasodilatation. The evidence that atenolol is cardioselective was presented initially in animal studies (Barrett et al., 1973). In man confirmation has been provided by studies of exercise heart rate and airways resistance (Vilsvik and Schaanning, 1976). However, there have been no direct studies of the action of atenolol on the peripheral vascular circulatory bed to establish the level of selectivity at this site in man. Until results of such studies are available the interpretation of changes in total peripheral resistance derived from haemodynamic studies of the type presented here will remain speculative.

The overall haemodynamic effects of atenolol described here at rest closely resemble those of intravenous propranolol in patients with coronary artery disease, but contrast with those of intravenous practolol (Åström, 1968; Jewitt et al., 1970). In 1972, Gibson and Coltart argued intuitively that the difference between the cardioselective agent practolol and the non-selective propranolol was the result of the cardioselectivity of practolol. They concluded that the modest fall in cardiac output that they had observed after practolol in patients with valvar heart disease was not a reflection of diminished force of left ventricular contraction, but of reduction in venous return produced by changes in the peripheral vascular bed. No direct measurements of these peripheral vascular changes were in fact made. The present evidence with atenolol suggests that this explanation may not be correct. It is clear that the final effects of any betablocking agent in man will depend not only on the relative dosage, the potency, and duration of betablocking effect produced, but also on the degree of cardioselectivity and magnitude of intrinsic sympathomimetic activity possessed. Though atenolol is said to be as cardioselective as practolol (Vilsvik and Schaanning, 1976), its haemodynamic effects more closely resemble those of propranolol at rest. The only major difference between practolol and atenolol is the possession of intrinsic sympathomimetic activity by practolol. It seems likely, therefore, that with practolol the combination of cardioselectivity and intrinsic sympathomimetic activity explains the observed differences from propranolol. Furthermore, at rest, cardioselectivity alone as in atenolol will not produce different hae.nodynamic effects from propranolol. Further confirmation that both intrinsic sympathomimetic activity and cardioselectivity in the same agent are relevant is suggested by the comparative studies of the effects of several beta-blocking drugs on the heart rate response to strenuous exercise performed by McDevitt et al. (1977). They demonstrated different heart rate responses to practolol and to atenolol and ascribed the difference to the intrinsic sympathomimetic properties of practolol.

In the present study, therefore, atenolol has produced haemodynamic effects at rest which closely resemble those found after intravenous propranolol in patients with coronary artery disease and differ from those that follow intravenous practolol. The haemodynamic actions of atenolol, which is cardioselective and has a long duration of action in man (Marlin et al., 1975; Harry, 1977), may confer advantages for the management of patients with angina pectoris.

\section{References}

Åström, H. (1968). Haemodynamic effects of beta-adrenergic blockade. British Heart fournal, 30, 44-49.

Åström, H., and Vallin, H. (1974). Effect of a new betaadrenergic blocking agent ICI 66082 , on exercise haemodynamics and airway resistance in angina pectoris. British Heart fournal, 36, 1194-1200.

Barrett, A. M., Carter, J., Fitzgerald, J. D., Hull, R., and Le Count, D. (1973). A new type of cardioselective adrenoceptive blocking drug. British fournal of Pharmacology, 48, 340p.

Brown, P., Baddeley, H., Read, A. E., Davies, J. D., and McGarry, J. (1974). Sclerosing peritonitis, an unusual reaction to a beta-adrenergic blocking drug (practolol). Lancet, 2, 1477-1481.

Conway, F. J., Fitzgerald, J. D. McAinsh, J., Rowlands, D. J., and Simpson, W. T. (1976). Human pharmacokinetic and 
pharmacodynamic studies on atenolol (ICI 66082), a new cardioselective beta-adrenoceptor blocking drug. British fournal of Clinical Pharmacology, 3, 267-272.

Epstein, S. E., and Braunwald, E. (1966). Beta-adrenergic receptor blocking drugs. Mechanisms of action and clinical applications. New England fournal of Medicine, 275, 1106-1112.

Felix, R. H., Ive, F. A., and Dahl, M. G. C. (1974). Cutaneous and ocular reactions to practolol. British Medical fournal, 4, 321-324.

Gibson, D. G, Balcon, R., and Sowton, E. (1968). Clinical use of ICI 50172 as an antidysrhythmic agent in heart failure. British Medical fournal, 3, 161-163.

Gibson, D. G., and Coltart, D. J. (1972). Haemodynamic effects of practolol. British Heart fournal, 34, 95-99.

Gibson, D., and Sowton, E. (1968). Effects of ICI 50172 in man during erect exercise. British Medical fournal, 1, 213215.

Gibson, D., and Sowton, E. (1969). The use of beta-adrenergic receptor blocking drugs in dysrhythmias. Progress in Cardiovascular Diseases, 12, 16-39.

Hamer, J., and Sowton, E. (1965). Cardiac output after betaadrenergic blockade in ischaemic heart disease. British Heart fournal, 27, 892-895.

Harry, J. D. (1977). The demonstration of atenolol as a betaadrenoreceptor blocking drug in man. Postgraduate Medical fournal, 53 (Suppl. 3), 65-69.

Jewitt, D. E., Burgess, P. A., and Shillingford, J. P. (1970). The circulatory effects of practolol (ICI 50172) in patients with acute myocardial infarction. Cardiovascular Research, 4, 188-193.

Jewitt, D. E., Mercer, C. J., and Shillingford, J. P. (1969). Practolol in the treatment of cardiac dysrhythmias due to acute myocardial infarction. Lancet, 2, 227-230.

Lesch, M., and Gorlin, R. (1973). Pharmacological therapy of angina pectoris. Modern Concepts of Cardiovascular Disease, 42, 5-10.

McDevitt, D. G., Brown, H. C., Carruthers, S. G., and Shanks, R. G. (1977). Observations on the influence of intrinsic sympathomimetic activity and cardioselectivity on beta-adrenoreceptor blockade in man. Clinical Pharmacology and Therapeutics, 21, 556-566.

MacDonald, A. G., and McNeill, R. S. (1968). A comparison of the effect on airway resistance of a new beta blocking drug ICI 50172 and propranolol. British fournal of Anaesthesia, 40, 508-510.

Marlin, G. E., Kumana, C. R., Kaye, C. M., Smith, D. M., and Turner, P. (1975). An investigation into cardiac and pulmonary beta-adrenoceptor blocking activity of ICI 66082 in man. British fournal of Clinical Pharmacology, 2, 151-157.

Mason, D. T., Spann, J. F., Jr., and Zelis, R. (1970). Quantification of the contractile state of the intact human heart. American fournal of Cardiology, 26, 248-257.

Powles, R., Shinebourne, E., and Hamer, J. (1969). Selective cardiac sympathetic blockade as an adjunct to bronchodilator therapy. Thorax, 24, 616-618.

Prichard, B. N. C., and Gillam, P. M. S. (1964). The use of propranolol (Inderal) in the treatment of hypertension. British Medical fournal, 2, 725-727.

Raftery, E. B., and Denman, A. M. (1973). Systemic lupus erythematosus syndrome induced by practolol. British Medical fournal, 2, 452-455.

Sowton, E., Balcon, R., Cross, D., and Frick, H. (1968). Haemodynamic effects of ICI 50172 in patients with ischaemic heart disease. British Medical fournal, 1, 215-216.

Vilsvik, J. S., and Schaanning, J. (1976). Effect of atenolol on ventilatory and cardiac function in asthma. British Medical fournal, 2, 453-455.

Wright, P. (1975). Untoward effects associated with practolol administration: oculomucocutaneous syndrome. British Medical fournal, 1, 595-598.

Requests for reprints to Dr. D. E. Jewitt, Cardiac Department, King's College Hospital, Denmark Hill, London SE5 9RS. 